УДК 616.833: 616.831.313-089

\title{
Костюк K.P.
}

\section{Стереотаксична передня калозотомія як метод хірургічного лікування тяжких форм симптоматичної епілепсії}

\author{
Інститут нейрохірургії ім. акад. А.П. Ромоданова НАМН України, м. Київ
}

\begin{abstract}
Вступ. Епілепсія є поліетіологічним, поширеним захворюванням нервової системи, яке діагностують в 1-2\% дорослого населення та $3-4 \%$ дітей. Більшість хворих успішно лікують з застосуванням антиепілептичних препаратів (АЕП), проте, тривале, іноді довічне використання АЕП спричиняє побічні реакції, навіть за повного контролю за епілептичними нападами. В той же час, майже $20-25 \%$ хворих на епілепсію резистентні до протисудорожної терапії, ім показане хірургічне лікування [1].

Хірургічне лікування епілепсії розвивається у двох основних напрямках, перший — класичні резекційні операції, другий - функціональні або паліативні хірургічні втручання. Функціональні операції використовують в ситуаціях, коли неможливо виконати резекцію епілептичного фокусу через його локалізацію у функціонально важливій ділянці мозку, наявність кількох епілептичних фрокусів, множинне ураження головного мозку, двобічні зміни електричної активності. До функціональних хірургічних втручань відносять калозотомію, множинну субпіальну трансекцію, різноманітні стереотаксичні втручання, включаючи радіохірургічні, а також електростимулюючі операції (стимуляція блукаючого нерва, глибинна стимуляція мозку, тривала коркова та мозочкові стимуляція) [1].
\end{abstract}

Мозолисте тіло є найбільшою за розмірами та важливістю нейрональною комісурою, яка з'єднує півкулі великого мозку. Через велику кількість міжнейрональних зв'язків у мозолистому тілі епілептичні розряди можуть швидко поширюватись 3 однієі півкулі в іншу і спричиняти генералізацію епілептичних нападів. Тому закономірним було припущення, що розсічення мозолистого тіла може сприяти блокуванню поширення епілептичної імпульсації з однієї півкулі в іншу, що запобігатиме вторинній генералізації нападів. Перше повідомлення про здійснення калозотомії з'явилося у 1940 р., коли учні Кушінга W.P. Van Wagenen i R.Y. Herron [2] доповіли про результати такого хірургічного втручання у хворих на епілепсію. Проте, до $60-\mathrm{x}$ років минулого сторіччя особливого інтересу до операції калозотомії у нейрохірургів не було, поки J.E. Bogen і співавтори [3] опублікували серію статей, в яких описали клінічні та нейрофізіологічні результати такої операції. У 1970 р. А.J. Luessenhop і співавтори [4] узагальнили результати виконання калозотомії у дітей як альтернативи гемісферектомії. 3 цього часу калозотомію у різних модифікаціях почали широко використовувати у нейрохірургічній практиці.

Метою калозотомії є попередження поширення епілептичної активності з однієї півкулі в другу шляхом переривання нервових сполучень, залучених у генералізацію епілептичної активності. Калозотомія перериває білатеральну синхронізацію, проте, лишає епілептичний фокус у мозку. Сьогодні не існує однозначних показань до виконання калозотоміі. Операція показана хворим при криптогенних, симптоматичних та ідіопатичних первинно генералізованих тонікоклонічних, атонічних нападах та дроп-атаках, які характеризуються раптовою втратою свідомості та падінням. За даними електроенцефалографії (ЕЕГ) у хворих виявляють білатеральну синхронізовану епілептичну активність [5-7]. У більшості хворих такі стани спостерігають при синдромі Веста, Леннокса-Гасто, енцефаліті Расмуссена, лобовій та мультифокальній епілепсії. Особливо широко застосовують калозотомію при лікуванні синдрому Леннокса-Гасто [8, 9].

Найбільш часто виконують передню калозотомію, розсікають мозолисте тіло від дзьоба до задньої третини його стовбура. Якщо позитивного ефекту від операції не спостерігають, у строки від кількох місяців до 2 років здійснюють другу операцію, під час якої розсікають залишену задню частину мозолистого тіла $[10,11]$. Такий період між операціями необхідний для зменшення ризику виникнення синдрому роз'єднання. За тяжкого перебігу епілепсії, дифузного багатовогнищевого ураження мозку виконують тотальну калозотомію в один етап [12-14]. Новітніми підходами до здійснення калозотомії є впровадження ендоскопічних, навігаційних, стереотаксичних, зокрема, радіохірургічних технологій [15-18].

Незважаючи на широке використання цієї операції, результати калозотомії різні. Це зумовлене відсутністю чіткої стандартизації анатомічних структур, що пересікають під час операції, та відсутністю критеріїв відбору пацієнтів до калозотомії з огляду на особливості перебігу хвороби, характер епілептичних нападів, дані електрофізіологічних та нейровізуалізаційних методів дослідження. В багатоцентровому дослідженні за участю 563 хворих, яким здійснено калозотомію, повне припинення епілептичних нападів відзначене у 7,6\% хворих, значне покращення - у $60,9 \%$, у $31,4 \%$ хворих частота нападів після операції не змінилася [19]. В інших дослідженнях припинення нападів спостерігали у $34 \%$ хворих, у $24 \%$ - частота нападів зменшилась більш ніж на $50 \%$, у $32 \%$ - не змінилася. Показано, що кращому контролю піддаються генералізовані атонічні напади, в той час як вираженість і частота парціальних нападів після калозотомії суттєво не змінюється [20-23].

За даними різних авторів, післяопераційна летальність при калозотомії становить від 0 до 6\%, транзиторні післяопераційні ускладнення виявляють у $20 \%$, постійні - у 5\%. Післяопераційними хірургічними ускладненнями мікрохірургічної калозотомії вважають гідроцефалію, асептичний менінгіт, кровотечу, повітряну емболізацію верхнього сагітального синусу, ішемію та набряк лобових часток мозку, запальне ураження. Можливе виникнення також специфічних фрунціональних ускладнень, насамперед, гострого синдрому пересічення, міжгемісферних сенсорних дисоціацій та синдрому розділення мозку 
(міжнародна назва Split-brain syndrome). Гострий синдром пересічення виявляють у більшості пацієнтів у ранньому післяопераційному періоді, він характеризується недомінантною апраксією або геміпарезом, двобічним хапальним рефлексом, порушенням уваги, нетриманням сечі, пригніченням спонтанної мови внаслідок розвитку мутизму [5, 21]. Міжгемісферні сенсорні дисоціації виникають через неможливість сприйняти візуальну, слухову або сомато-сенсорну інформацію і правильно їі інтерпретувати [14]. Синдром розділення характеризується гемісферним “змаганням”, розладами мови, пам'яті, концентрації уваги.

3 огляду на складність та травматичність мікрохірургічної калозотомії, запропонований метод стереотаксичної передньої калозотомії [24], яку в Росії розвинув А.С. Шершевер [15]. Для обчислення координат мішені деструкції автор спочатку використовував дані МРТ, вентрикулографії та церебральної ангіографії, пізніше - стереотаксичної системи Leibinger та програмне забезпечення Stryker на основі реконструкції MPT, КТ зображень.

Метою роботи $є$ оцінка ефективності стереотаксичної передньої калозотомії у хворих за тяжкої форми симптоматичної епілепсії.

Матеріали і методи дослідження. У відділенні фонкціональної нейрохірургії вперше в Україні здійснена стереотаксична передня калозотомія у 5 хворих з приводу симптоматичної фармакорезистентної епілепсії, з яких було 3 дітей.

У 4 хворих напади були парціальними з вторинною генералізацією, в 1 - первинно генералізованими. До моменту операції хворі застосовували від 3 до 8 різних (у середньому -4) АЕП у вигляді моно- або політерапії. У 4 хворих епілептичні напади виникли у строки до 6 міс життя, в $1-$ у віці 14 років. Напади були щоденними у 4 хворих (3 дітей і 1 дорослого). В одному спостереженні частота нападів 10-15 щомісяця. В усіх хворих в анамнезі були відомості про повторний епілептичний статус. У 2 дітей під час дослідження психічного статусу виявлені виражені когнітивні розлади. Таким чином, наведені дані свідчили про наявність у хворих фармакорезистентної форми епілепсіі.

За даними MPT у 3 дітей виявлені аномалії розвитку головного мозку у вигляді гіпоплазії мозолистого тіла (у 2) та порожнини прозорої перегородки. В однієї жінки віком 28 років відзначені рубцевоатрофічні зміни правої лобово-скроневої ділянки головного мозку як наслідок перенесеної пологової травми. В одного хворого віком 20 років не виявлені структурні зміни півкуль великого мозку, проте, у віці 14 років йому здійснено операцію - видалення пухлини черв'яка та лівої півкулі мозочка (висновок гістологічного дослідження: астроцитома фібрилярно-протоплазматична). Через 2 роки після операції виникли епілептичні напади генералізовані атонічні, тонічні i, незважаючи на застосування різних АЕП, частота нападів збільшилась до щоденних. На момент виконання стереотаксичної калозотомії дані щодо продовженого росту пухлини не виявлені.

У 2 дітей віком 4 і 11 років за характером епілептичних нападів та перебігом хвороби діагностований синдром Леннокса - Гасто. Напади виникли відповідно на 1-му та 6-му місяці життя. В обох хворих переважали атонічні, міоклонічно-астатичні, комплексні парціальні напади та дроп-атаки. Епілептичні зміни на ЕЕГ представлені уповільненою генералізованою, білатеральною синхронізованою активністю. При цьому характерні для синдрому Леннокса - Гасто комплекси пік-хвиля частотою 1-2,5 Гц не виявлені.

Хірургічне втручання здійснювали з використанням стереотаксичної системи CRW Radionics (США). За кілька днів до операції проводили МРТ головного мозку у T2WI та T1WI режимах, товщина зрізів 2 мм. На початку операції на голові хворого фріксували стереотаксичну рамку, до якої закріплювали локалайзер і проводили КТ головного мозку за допомогою спірального томографа, товщина зрізів 1,25 мм. Використовуючи комп'ютерні програми StereoFusion, StereoPlan, співставляли ("fusion") MPT- і КТзображення, після чого обчислювали координати мішені деструкції. Безпосередньо перед операцією на фантомі перевіряли точність встановлення координат. Операцію виконували під внутрішньовенним наркозом. Фрезовий отвір накладали у задньолобовій ділянці діаметром 7-8 мм. Високочастотну електролітичну деструкцію здійснювали з використанням електродів 3 робочою поверхнею діаметром $2,1 \mathrm{~mm}$, довжиною 5 мм. Температура робочої частини електрода під час деструкції становила $80^{\circ} \mathrm{C}$, тривалість експозиції деструкції 60 с. Формували п'ять вогнищ деструкції: два - у нижніх та верхніх відділах коліна, три - послідовно у передніх відділах стовбура мозолистого тіла на відстані 3-4 мм один від одного Після операції хворих направляли у відділення.

Результати та їх обговорення. Всі хворі перенесли стереотаксичне втручання добре, післяопераційних ускладнень не було. Пацієнтів виписували на 7-8-му добу. Тривалість спостереження від 3 до 18 міс (у середньому 11 міс). 3 метою об'єктивної оцінки результатів операції антиепілептичну терапію протягом 6 міс після операції не змінювали.

В одному спостереженні епілептичні напади припинилися (шкала Енгела 1), у 2 хворих частота нападів зменшилась більш ніж на $90 \%$, у 2 - більш ніж на $50 \%$ (шкала Енгела 3). У 3 хворих, у яких до операції напади були парціальні 3 вторинною генералізацією, після операції виявляли короткочасні парціальні напади, частота яких значно зменшилась. Це свідчило про блокування поширення епілептичної активності з інтактного епілептичного фокусу у протилежну півкулю. Наводимо клінічне спостереження.

Хвора 3., 28 років, обстежена в клініці. Встановлений діагноз: симптоматична епілепсія з простими парціальними нападами, вторинною генералізацією, фармакорезистентна форма, правобічна геміатрофія головного мозку як наслідок пологової травми (puc. 1). Епілептичні напади виникли на другому місяці життя. Застосовувала 6 АЕП, проте, частота епілептичних нападів лишалась високою - до 2 на добу. За даними МРТ вогнищеві структурні зміни у правій півкулі мозку не виявлені, в той же час за даними електрофізіологічних досліджень спостерігали епілептичну активність у лівій лобово-скроневій ділянці мозку, яка поширювалась на протилежну півкулю. Характер епілептичних змін електричної активності мозку відповідав клінічним проявам епілептичних нападів: напади починалися з тонічного напруження правих кінцівок, більше верхньої, з по- 
дальшою втратою свідомості, падінням, тоніко-клонічними судорогами.

18.03.10 виконана операція: стереотаксична передня калозотомія зліва (puc. 2). Ускладнень не було, після операції антиепілептичну терапію не змінювали. Тривалість спостереження 15 міс. У 1-й місяць після операції у хворої виникли 3 короткочасні прості парціальні сенсорні напади у вигляді парестезії у правій верхній кінцівці, після чого напади припинились. За даними контрольної ЕЕГ виявлено значну асиметрію розподілу епілептичної активності між півкулями головного мозку. Якщо до операції різниця патологічної активності між генеруючою епілептичну активність лівою півкулею та протилежною правою була незначною (коефіцієнт асиметрії - КА становив $31 \%$ ), після операції спостерігали значне переважання патологічної активності в ураженій лівій півкулі (КА $68 \%$ ). Ці дані свідчать про блокування поширення патологічної імпульсації з однієї півкулі в іншу. Оцінка ефективності хірургічного лікування за шкалою Енгела - 1 (рис. 3).

Отримані попередні дані свідчать, що стереотаксична передня калозотомія є ефрективним та безпечним методом хірургічного лікування тяжких форм симптоматичної епілепсії за неможливості здійснення резекції епілептичного фокусу. Незважаючи на паліативний характер оперативного втручання, в усіх хворих вдалося досягти позитивного ефректу, причому в одному спостереженні епілептичні напади повністю припинилися, у 2 - іх частота зменшилась більш ніж на 90\%. Ускладнень під час операції та після неї не було. Після операції хворим не потрібне було перебування у відділенні інтенсивної терапії та тривала післяопераційна реабілітація.

Впроваджений метод стереотаксичної передньої калозотомії є перспективним напрямком хірургічного лікування тяжких фрорм епілепсії. На відміну від мікрохірургічної калозотомії, стереотаксична калозотомія є малотравматичним хірургічним втручанням з низьким ризиком виникнення неврологічних ускладнень. Операція не потребує тривалого застосування інтубаційного наркозу, перебування хворого у відділені інтенсивної терапії, тривалої післяопераційної реабілітації, що зменшує витрати на лікування хворих.

Проведене дослідження дозволяє зробити попередні висновки.

1. Застосування стереотаксичної передньої калозотомії під час лікування тяжких форм симптоматичної епілепсії є ефективним і малотравматичним
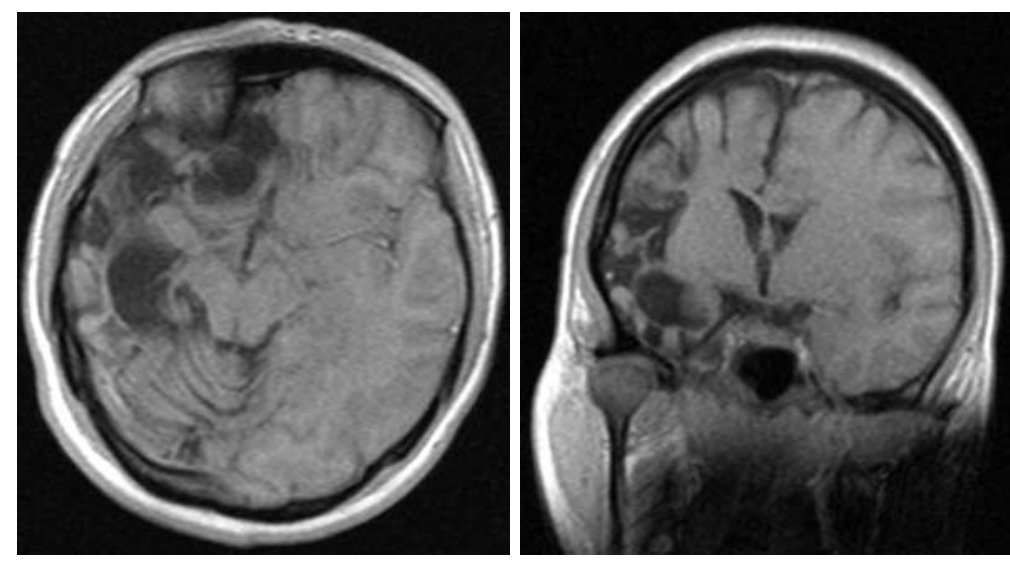

Puc. 1. Хвора 3. МРТ головного мозку до операції. Рубцево-атрофічні зміни правої лобово-скроневої ділянки головного мозку.


Puc. 2. Хвора 3. Обчислення стереотаксичної термодеструкції передньої третини мозолистого тіла. Під час операції використані комп'ютерні програми StereoFusion та StereoPlan стереотаксичної системи Radionics. Зображені перша та остання п’ята мішені деструкції. Між ними містяться ще три мішені.
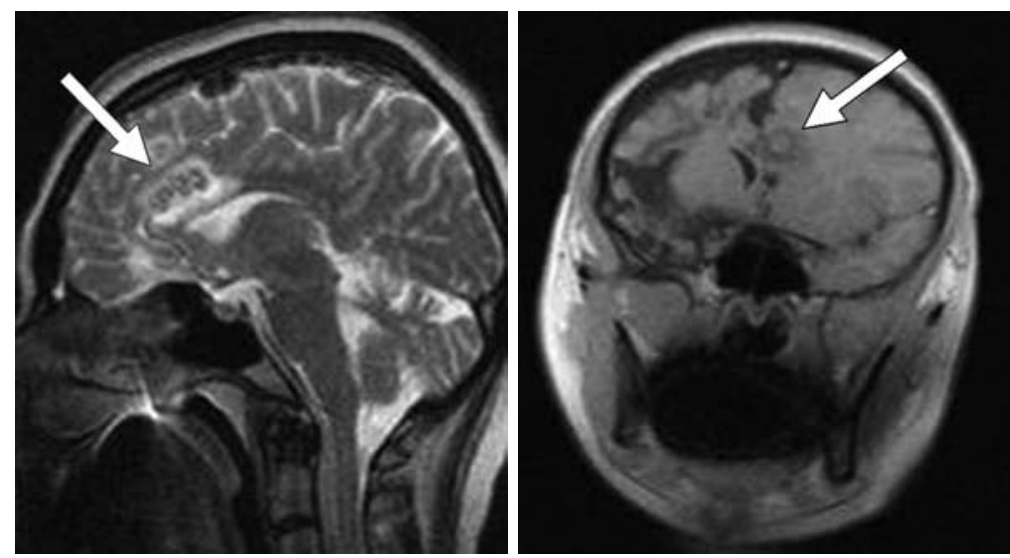

Puc. 3. Хвора 3. МРТ головного мозку через 12 міс після термодеструкції передньої третини мозолистого тіла.

методом, який може бути рекомендований для більш широкого застосування.

2. Метод стереотаксичної передньої калозотомії потребує подальшого поглибленого вивчення для розширення показань до його застосування, удосконалення самого методу з метою покращення результатів хірургічного лікування тяжких форм епілепсії. 


\section{Список літератури}

1. French J.A. Therapeutic strategies in epilepsy / J.A. French, N. Delanty. — Oxford: Clin. Publish., 2009. — 341 p.

2. Van Wagenen W.P. Surgical division of commissural pathways in the corpus callosum. Relation to spread of an epileptic attack / W.P. Van Wagenen, R.Y. Herron // Arch. Neurol. Psychyat. - 1940. - V.44. - P.740-759.

3. Bogen J.E. Treatment of generalized by cerebral commissurotomy / J.E. Bogen, P.J. Vogel // Surg. Forum. - 1963. - V.14. - P.431-433.

4. Luessenhop A.J. Surgical disconnection of cerebral hemispheres for intractable seizures: results in infancy and childhood / A.J. Luessenhop, T.C. Cruz, G.M. Fenichel // J.A.M.A. — 1970. - V.231. - P.1630-1636.

5. Bogen J.E. Callosal lesions and behavior: History and modern concepts / J.E. Bogen, P.J. Vogel // Epilepsy Behav. - 2003 - V.4. - P.607-617.

6. Corpus callosotomy / A.A. Asadi-Pooya, A. Sharan, M. Nei, M.R. Sperling // Epilepsy Behav. - 2008. - V.13, N2. - P.271-278.

7. Corpus callosotomy in refractory idiopathic generalized epilepsy / S. Jenssen, M.R. Sperling, J.I. Tracy [et al.] // Seizure. - 2006. - V.15, N8. - P.621-629.

8. Comparison of corpus callosotomy and vagus nerve stimulation in children with Lennox-Gastaut syndrome / S.J. You, H.C. Kang, T.S. Ko [et al.] // Brain Dev. — 2008. - V.30, N3. - P.195-199.

9. Corpus callosotomy in a patient of hemimegalencephaly and Lennox - Gastaut syndrome / S.Y. Kwan, H.Y. Shyu, J.H. Lin [et al.] // Brain Dev. - 2008. - V.30, N10. - P.643-646.

10. Changing the paradigm of 1-stage total callosotomy for the treatment of pediatric generalized epilepsy / K.W. Shim, Y.M. Lee, H.D. Kim [et al.] // J. Neurosurg. Pediatr. - 2008. - V.2, N1. - P.29-36.

11. Corpus callosotomy for treatment of pediatric epilepsy in the modern era / S.Y. Rahimi, Y.D. Park, M.R. Witcher [et al.] // Pediatr. Neurosurg. - 2007. — V.43, N3. — P.202-208.

12. Complete versus anterior two-thirds corpus callosotomy in children: analysis of outcome / L. Jalilian, D.D. Limbrick, K. Steger-May [et al.] // J. Neurosurg. Pediatr. - 2010. - V.6, N3. - P.257-266.
13. Outcome after extended callosal section in patients with primary idiopathic generalized epilepsy / A. Cukiert, J.A. Burattini, P.P. Mariani [et al.] // Epilepsia. — 2009. — V.50, N6. - P.1377-1380.

14. Roberts D.W. Section of the corpus callosum for epilepsy / D.W. Roberts // Operative neurosurgical techniques; ed. H. Schmidek. — Sweet, 1995. — 3rd ed. - P.1351-1358.

15. Шершевер А.С. Хирургическое лечение эпилепсии / А.С. Шершевер. - Екатеринбург: АПРИО, 2005. - 164 с.

16. Corpus callosotomy using conformal stereotactic radiosurgery / M.A. Celis, S. Moreno-Jiménez, J.M. Lárraga-Gutiérrez [et al.] // Childs Nerv. Syst. - 2007. - V.23, N8. - P.917-920.

17. Efficacy and safety of radiosurgical callosotomy: a retrospective analysis / M. Feichtinger, O. Schröttner, H. Eder [et al.] // Epilepsia. — 2006. - V.47, N7. - P.1184-1191.

18. Image-guided, frameless stereotactic sectioning of the corpus callosum in children with intractable epilepsy / M. Hodaie, A. Musharbash, H. Otsubo [et al.] // Pediatr. Neurosurg. - 2001. - V.34. - P.286-294.

19. Outcome with respect to epileptic seizures / J. Engel, P.C. Van Ness, T.B. Rasmussen, LM. Ojemann // Surgical Treatment of the Epilepsies; ed. J. Engel. - N.Y.: Raven Press, 1993. - 2nd ed. - P.609-621.

20. Long-term seizure outcome after corpus callosotomy: a retrospective analysis of 95 patients / T. Tanriverdi, A Olivier, N. Poulin [et al.] // J. Neurosurg. — 2009. — V.110, N2. - P.332-342.

21. Lucas T.H. Corpus callosotomy: Indications, surgical procedures and outcome / T.H. Lucas, G.A. West // Epilepsy Surgery: Principles and Controversies; ed. J.W. Miller, D.L. Silbergeld. — New York; London: Naylor and Francis Group, 2006. - P.541-551.

22. Spencer $\mathrm{S}$. Anterior, total and two-stage corpus callosum section: differential and incremental seizure responses / S Spencer, D. Spencer, K. Sass // Epilepsia. - 1993. - V.34 - P.561-567.

23. Sunaga S. Long-term follow-up of seizure outcomes after corpus callosotomy / S. Sunaga, H. Shimizu, H. Sugano // Seizure. - 2009. — V.18, N2. - P.124-128.

24. Laitinen L.V. Stereotactic lesion in the knee of the corpus callosum in the treatment of emotional disorders / L.V. Laitinen // Lancet. - 1972. - V.1. - P.472-475.

Одержано 08.07.11

\section{Костюк К.P.}

\section{Стереотаксична передня калозотомія як метод хірургічного лікування тяжких форм симптоматичної епілепсії}

Інститут нейрохірургії ім. акад. А.П. Ромоданова НАМН України, м. Київ

Оцінені результати стереотаксичної передньої калозотомії у хворих з первинними та вторинними генералізованими епілептичними нападами за неможливості здійснити резекцію епілептичного фокусу.

Стереотаксична калозотомія виконана у 5 хворих (з них 3 дітей), у яких встановлена симптоматична епілепсія, у 4 - напади були щоденними. В усіх хворих в анамнезі були відомості про повторний епілептичний статус. У 4 хворих напади були з вторинною генералізацією, в 1 — первинно генералізовані. Післяопераційних ускладнень не було, хворі виписані на 7-8-му добу після операції. У строки спостереження від 3 до 18 міс, у середньому 11 міс, в 1 хворого напади припинилися, у 2 - іх частота зменшилась більш ніж на 90\%, у 2 - більш ніж на $50 \%$.

Результати дослідження свідчать, що стереотаксична калозотомія є безпечним паліативним методом хірургічного втручання і може бути рекомендована хворим при симптоматичній фармакорезистентній епілепсії за неможливості виконати резекцію епілептичного фокусу.

Ключові слова: симптоматична епілепсія, епілептичні напади, стереотаксична передня калозотомія. 


\section{Костюк К.P.}

\section{Стереотаксическая передняя калозотомия как метод хирургического лечения тяжелых форм симптоматической эпилепсии}

Институт нейрохирургии им. акад. А.П. Ромоданова НАМН Украины, г. Киев

Оценены результаты стереотаксической передней калозотомии у больных при первично и вторично генерализованых эпилептических припадках, у которых невозможно выполнить резекцию эпилептического фокуса.

Стереотаксическая калозотомия произведена 5 больным (из них 3 детей), у которых диагностирована симптоматическая эпилепсия. У 4 больных припадки были ежедневными, у 1 - первично генерализованными. Послеоперационных осложнений не было, все пациенты выписаны на 7-8-е сутки после операции. В сроки наблюдения от 3 до 18 мес, в среднем 11 мес, у 1 больного припадки прекратились, у 2 - их частота уменьшилась более чем на $90 \%$, у 2 — более чем на $50 \%$.

Результаты исследования свидетельствуют, что стереотаксическая калозотомия является безопасным паллиативным методом хирургического вмешательства и может быть рекомендована больным при симптоматической фармакорезистентной эпилепсии, у которых невозможно осуществить резекцию эпилептического фокуса.

Ключевые слова: симптоматическая эпилепсия, эпилептические припаджи, стереотаксическая передня калозотомия.

\section{Kostyuk K.R.}

\section{Stereotactic anterior callosotomy as a treatment method of severe forms of symptomatic epilepsy \\ Institute of Neurosurgery named after acad. A.P. Romodanov of National Academy of Medical Sciences of Ukraine, Kiev}

The results of stereotactic anterior callosotomy in patients with primary and secondarily generalized seizure, at whom epileptic focus resection was impossible, were estimated.

Stereotactic callosotomy was performed in 5 patients (there were 3 children among them) with symptomatic epilepsy. 4 patients had daily seizures, 1 - primary generalized seizures. There were no postoperative complications, all patients were discharged on the $7-8^{\text {th }}$ day after surgery. The postoperative follow-up was from 3 to 18 months, in average 11 months, one patient became seizure free, in 2 - the seizures' frequency decreased for $90 \%$ and, in other 2 patients - for $50 \%$ and more.

The results of the research confirm that stereotactic callosotomy is a safe palliative surgical method and may recommended for patients with drug-resistant symptomatic epilepsy, at whom epileptic focus resection is impossible.

Key words: symptomatic epilepsy, seizures, stereotactic anterior callosotomy.

\section{Комментарий \\ к статье К.Р. Костюка “Стереотаксична передня калозотомія як метод хірургічного лікуВання тяжких форм симптоматичної епілепсії”}

Статья посвящена актуальной проблеме эпилептологии - хирургическому лечению тяжелых фармакорезистентных форм симптоматической эпилепсии. Учитывая новизну операций стереотаксической передней каллезотомии для Украины, объяснимо небольшое число больных и непродолжительный период наблюдения. Во вступлении автор в достаточной степени анализирует эфрфективность существующих хирургических методов лечения (гемисферэктомия, открытая микрохирургическая каллезотомия, нейростимуляция блуждающего нерва) и обосновывает теоретические аспекты стереотаксической каллезотомии, ее преимущества и недостатки, и главное - отбор пациентов для этого вмешательства. Подробно описана технология выполнения стереотаксической передней каллезотомии, иллюстрированная данными МРТ до операции, во время стереотаксического планирования и после операции, что может стать большим подспорьем для освоения этого перспективного метода в нейрохирур- гических отделениях Украины.

Большую помощь автору в диагностике и хирургическом планировании могли бы оказать тест Вада (Wada test) для определения доминантного полушария и функциональная MPT (f MRI) головного мозга с трактографией для визуализации транскаллезных волокон, позволяющая определить протяженность деструкции мозолистого тела.

Описанным клиническим наблюдением и результатами хирургического лечения других пациентов автор доказывает перспективность стереотаксической передней каллезотомии в лечении пациентов с симптоматическими фармакорезистентными формами эпилепсии на основании относительно высокой эффективности, малотравматичности вмешательства, низкого риска возникновения неврологических осложнений, а также экономической целесообразности, связанной с реанимационно-анестезиологическим пособием и реабилитацией больных.

Д.Ю. Латышев, канд. мед. наук, заведующий отделением сосудистой нейрохирургии Днепропетровской областной клинической психиатрической больнищы 